Historic, Archive Document

Do not assume content reflects current scientific knowledge, policies, or practices. 



\section{TRADE PRICE LIST}

\section{Of Choice Young Nursery-Grown Ornamental Trees, Vines, Perennial Plants and Bulbs Fruit Trees and Small Fruits}

\section{ATLANTIC NURSERY CO. \\ INCORPORATED}

BERLIN, MARYLAND.

\section{ANNOUNCEMENT TO THE TRADE,--}

We take pleasure in handing you this list. In it you will find attractive prices for carefully grown and strictly first-class stock that cannot fail to please. We have the soil, climate and experience to grow trees and bulbs to perfection.

You like good stock and good treatment; everyone does; we pride ourselves on our stock and service. We appreciate your patronage, and want you to know it. We want you to come again. That's why we guarantee you entire satisfaction.

Our seedling orders sre filled direct from the ground-No Cellared or Stored Stock. You get your plants and trees fresh and alive. This means much to you. Think it over before buying from abroad. Early orders will please us, and you may rest assured we will do our best to please you.

Prices in this list abrogate previous quotations, and are subject to change without notice.

Prices in this list are for the trade only and are subject to the stock being unsold when order is received. Orders are subject to loss by frost, hail or any other cause over which I have no control. Prices include careful packing in the best manner. Boxes and barrels at cost. 250 of a kind at the thousand rate. Special prices on large quantities. Send us your list of wants and we will gladly price them.

In No Case will we be responsible for goods after consignment to purchaser and delivery to forwarding agent. When losses occur by delay or other cause, of whatever nature, while goods are at terminals or in transit, make claim at once on forwarding companies.

A CLEAN BILL OF HFALTH from the State Entomologist accompanies all orders. The greatest care is exercised to have and keep everything true-to-name and as represented. We will replace all that prove otherwise, or refund money paid for same. But in no case shall we be liable for a greater sum than originally paid.

TERIIS-Cash, or satisfactory reference from unknown parties.

Visitors are always welcome and we will be pleased to show you our stock and our country and make your trip both pleasant and profitable to you, as well as to ourselves. 


\section{Deciduous Trees, Shrubs and Vines.}

\section{Seedlings for Lining Out, Etc.}

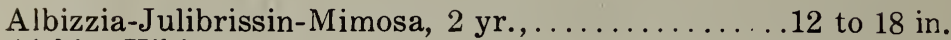

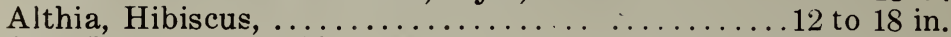
Acer Dasycarpum, Silver Maple,...........6 to 12 in. Acer Dasycarpum, Silver Maple, ............... 12 to 18 in. Acer Negundo, Western Box Elder, ..........6 to 12 in. Acer Negundo, Western Box Elder, ............12 to 18in. Acer Platanoides, Norway Maple, (trans) ....... 3 to $4 \mathrm{ft}$. Acer Pseude-platanus, Sycamore Maple........ 4 to $6{ }^{\circ} \mathrm{in}$. Acer Saccharum, Sugar Maple, ............ 8 to 12 in. Amorpha Fruitcosa,................... 4 to 6 in. Ailanthus, Tree of Heaven, .................. Ampelopsis Englemanni, ................... Ampelopsis, Englemanni, (trans.) ............ 2 to $3 \mathrm{ft}$. Aralia Pentaphylla, .............................

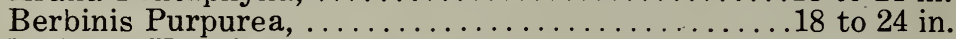
Buddleia-Variabilis, (strong trans.)......... 3 to $4 \mathrm{ft}$. each Buddleia-Lyndiana, " " “ .......... 3 to $4 \mathrm{ft}$. each Buddleia-Veitchii, “ “ “ $\ldots \ldots \ldots \ldots . . .3$ to $4 \mathrm{ft}$. each Buddleia-Veitchii-Magnifica “ $\quad \ldots \ldots \ldots \ldots 3$ to $4 \mathrm{ft}$. each Berberis-Thunbergii, Japanese Barberry, ........ 1 year old Berberis-Thunbergii, (trans.) .................. 18 to 24 in. Berberis-Thunbergii, (trans.) bushy ........... 2 to $3 \mathrm{ft}$. Calycanthus, Sweet Shrub, .. ............. Calycanthus, .......................... 12 to 18 in. Carpinus Americana, American Hornbeam, ...... 8 to 12 in. Catalpa Bungeii, strong 3 yr. heads.........4 to $5 \mathrm{ft}$. each Catalpa-Speciosa, true Western,............. 2 to $3 \mathrm{ft}$. Catalpa-Speciosa, true Western, (trans.) ........ 3 to $5 \mathrm{ft}$. Catalpa-Speciosa, true IVestern, (trans.).......6 to $10 \mathrm{ft}$. Cephalanthus Occidentalis, Button ball bush, .....12 to 18 in. Cercis-Canadinsis, Red Bud,...............6 to 12 in. Cassia Marylandica, ........................... 2 year old Citrus Trifolata, Hardy Orange, (trans.) ....... 2 to $3 \mathrm{ft}$. Cornus-florada, ....................... 4 to 6 in. Cornus-Sanguinea, (trans.) ........................ Cornus-Sanguinea, (trans.) ............... Cornus Siberica,........................ 6 to 12 in.

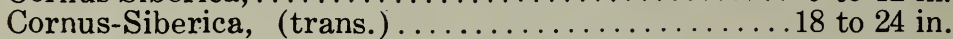
Cornns Siberica, Red Dogwood, (trans.)......... 2 to $3 \mathrm{ft}$. Cornus Stolonifera, (trans.) .................. 2 to $3 \mathrm{ft}$.

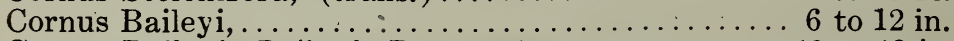
Cornus Baileyi, Bailey's Dogwood, ..........12 to 18 in. Cornus Amomum, Silky Dogwood,.............. 18 to 24 in. Cornus Sanguinea, ............................ 6 to 12 in. Cornus Lutea,....................... 6 to 12 in. Celastrus Articulata, Jap. Bitter Sweet, .......... 12 to 24 in. Clematis Coccenia,................................ 3 year, each Clematis Crispa,.................. “ “ “ “ Crepe Myrtle, Pink,............... “ ، “ ،

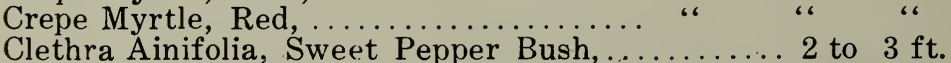
Deutzia Gracilis, (trans. )..................... 12 to 18 in. Deutzia Rosea, “ $\ldots \ldots \ldots \ldots \ldots \ldots \ldots \ldots \ldots \ldots \ldots \ldots \ldots \ldots \ldots \ldots \ldots \ldots$ to 18 in. Deutzia Lemoine, if “ $\ldots \ldots \ldots \ldots \ldots \ldots \ldots \ldots \ldots \ldots \ldots \ldots \ldots \ldots \ldots \ldots$ to 18 in. Deutzia Watereri, New Single Pink, ......... 8 to 12 in. Deutzia Wellsi, New Double White, ........... 8 to 12 in. Deutzia Candidissima,................... 6 to 12 in. Deutzia Candidissima, Plena, (white) .............. 2 to $3 \mathrm{ft}$. Deutzia Candidissima, Plena.................. 3 to $5 \mathrm{ft}$.

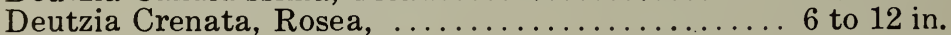
Deutzia Crenata, Rosea ....................... 2 to $3 \mathrm{ft}$. Deutzia Crenata, Rosea .................... 3 to $5 \mathrm{ft}$. Deutzia Pride of Rochester, ..............6 to 12 in.

Per 1000

$\$ 3000$

1000

300

500

400

600

7500

500

1000

500

1000

$30 \quad 00$

10000

8000

$50 \quad 00$

35

35

35

35

1000

5000

8000

1000

1500

1000

50

1000

3000

10000

3000

800

3000

$\begin{array}{ll}50 & 00\end{array}$

1500

$40 \quad 00$

$\begin{array}{ll}75 & 00\end{array}$

2000

4000

$\begin{array}{ll}75 & 00\end{array}$

5000

$\begin{array}{ll}30 & 00\end{array}$

7500

5000

2000

3500

$\begin{array}{ll}75 & 00\end{array}$

15

15

15

25

2000

10000

10000

10000

3000

3000

2000

3000

6000

2000

2500

5000

2000 
Deutzia Pride of Rochester, (white) ............ 3 to $5 \mathrm{ft}$. Diospyros Virginiana, Persimmon,............. 12 to 18 in. Euonymus Americana, ............................. 12 to in. Euonymus Bungeanus, .................... Fagus-ferruginea, American Beech, ......... Forsythia-Sieboldi, Jap. Golden Bell, ............ Forsythia Verdissima, Golden Bell.............. 12 to 18 in. Forsythia Verdissima, Golden Bell, ............. 2 to $3 \mathrm{ft}$. Fraxinus Viridis, Green Ash................. 6 to 12 in. Fraxinus Viridis, (trans.) ............... 5 to $8 \mathrm{ft}$. Fraxinus Viridis, (trans.) ...................... 8 to $10 \mathrm{ft}$. Genista-juncea, Sweet Spanish Broom,............ 12 to 18 in. Genista Scoparia, Scotch Broom .............. 2 to $3 \mathrm{ft}$. Genista Scoparia, Scotch Broom .....Specimens, 3 to $5 \mathrm{ft}$. each Gleditschia-triacanthos, Honey Locust......... 3 to 6 in. Gleditschia-triacanthos, Honey Locust, ......... 6 to 12 in. Hickory Minina, Bitter nut................. 6 to 10 in. Hickory Ovata, Shellbark or Shagbark, ......... 6 to 8 in. Hickory Tomentosa, White Hickory, ............. 6 to 8 in. Hickory Tomentosa, White Hickory, ............ Hydrangea, A. G.,.................. 2 to $3 \mathrm{ft}$. Hydrangea, P. G.,....................... 18 to 24 in. Hydrangea, P. G., ....................... 2 to $3 \mathrm{ft}$. Hydrangea, P. G.,.................... 3 to $4 \mathrm{ft}$. Hypericum, St. John's Wort Yellow,............ 3 year Juniperus Virginiana, .................. 2 to 4 in. Juglans-Cineria, Butternut, ................. Juglans-Cineria, Butternut, (trans.).............. Juglans-Cineria, Butternut; (trans.) ........... 2 to $3 \mathrm{ft}$. Juglans-Cineria, Butternut, (trans.) ........... 3 to $4 \mathrm{ft}$. Juglans-Sieboldi, Japan Walnut,.............. 8 to 12 in. Liriodendron Tulipifera, Tulip Tree, (trans.) . 8 to $10 \mathrm{ft}$. each Liriodendron Tulipifera, Tulip Tree, (trans.) ..... 5 to $6 \mathrm{ft}$. Ligustrum Ovalifolium, Cal. Privet, ............ Ligustrum Ovalifolium, Cal. Privet............. Ligustrum Ovalifolium, Cal. Privet,............ 18 to 24 in. Ligustrum Ovalifolium, Cal. Privet, .......... 2 to $3 \mathrm{ft}$. Ligustrum Ovalifolium, bushy ............... 3 to $5 \mathrm{ft}$. Ligustrum Ovalifolium, Cal. Privet (extra heavy). 5 to $6 \mathrm{ft}$. Ligustrum Ibota, Ibota Privet, (cuttings)........6 to 12 in.

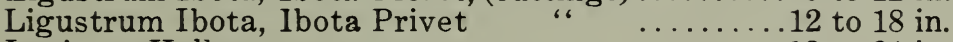
Lonicera Halleana ....................... 18 to 24 in.

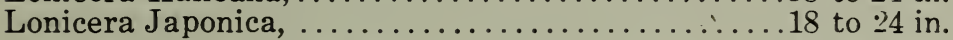

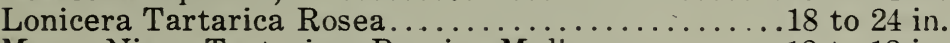
Morus-Nigra Tartarica, Russian Mulberry, ........ 12 to 18 in. Morus-Nigra Tartarica, Russian Mulberry, (trans.) 4 to $6 \mathrm{ft}$. Morus-Nigra Tartarica, (trans.) ............... 6 to $8 \mathrm{ft}$. Myrica Cerifera, Wax Myrtle,.................. 18 to 24 in. Malus Coronarius, Sweet Flowering Crab,......6 to 12 in. Malus Coronarius, Sweet Flowering Crab,......... 12 to 18 in. Malus Pendula Elsie Rathka, Weeping Apple, new, rare; standards, ................... 7 to $8 \mathrm{ft}$. each Malus Pendula Elsie Rathka, Weeping Apple,

new, rare; standards, .................. 8 to $10 \mathrm{ft}$. each Oxydendrum Arborea, (trans. ) ................. 8 to 12 in. Osage Orange, ................................ 4 to 6 in.

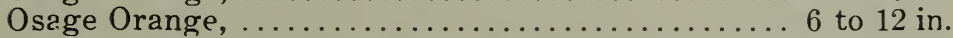
Opulaster-Ramiley, Colo. Ninebark, ............ 2 to $3 \mathrm{ft}$. Prunus-Americana, ....................... 3 to $4 \mathrm{ft}$. Prunus-Americana, .................................. 4 to $6 \mathrm{ft}$. Pyrus Arbıtifolia-Chokeberry, .................... Populus-Suaveolens, Extra fine Poplar from China; very hardy and strong grown, .............. 3 to $4 \mathrm{ft}$. Populus- Siemonii, Very hardy Russian Poplar, strong grown and ornamental,............. 3 to $4 \mathrm{ft}$.
Per 1000

6000

1500

2000

6000

2000

$50 \quad 00$

3000

10000

500

10000

25000

10000

$100 \quad 00$

25

500

600

1500

2000

1500

2500

10000

50 00

$\begin{array}{ll}75 & 00\end{array}$

12500

10000

1000

500

1500

2500

5000

$20 \quad 00$

30

15000

600

1000

1500

2000

3500

5000

1000

2500

2000

2000

2000

600

6000

10000

7500

1500

2000

100

200

4000

200

400

4000

8000

$100 \quad 00$

$75 \quad 00$

10000

10000 
Populus, Sp. Chope Poplar from Spain, ......... 3 to $4 \mathrm{ft}$. Pinus Ponderosa, 2 year, .................. Pinus Resinosa, “

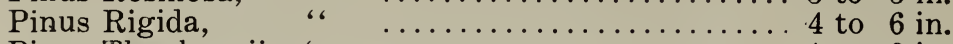

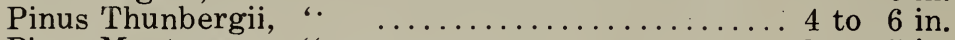

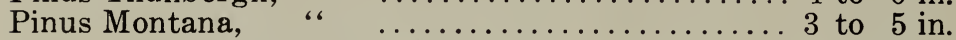
Pecan, from extra choice Md. nuts, ............. 6 to 12 in. Pecan, from extra choice $M d$. nuts, .............. Platanus Occidentalis, Buttonwood (trans.) ......... 2 to $3 \mathrm{ft}$. Platanus Occidentalis, (trans.) nice heads, ........ 8 to $12 \mathrm{ft}$.. Platanus Orientalis, European Plane, (trans.) .... 8 to $12 \mathrm{ft}$.

Our Planes are grown from cuttings and are uniform in type. Populus Carolinensis, ..................... 5 to $6 \mathrm{ft}$. Populus fastigiata, Lombardy Popular, .......... 1 to $2 \mathrm{ft}$. Populus fastigiata, Lombardy Popular, ......... 2 to $3 \mathrm{ft}$. Populus Volga, an extra fine sort, .............. 3 to $4 \mathrm{ft}$. Populus Norway, The Sudden Sawlog........... 4 to $5 \mathrm{ft}$. Quercus Falcata, Spanish Oak, ............. 6 to 12 in. Quercus Illicifolia, Bear Oak,............... 6 to 12 in. Quercus Nigra, Scrub Oak,.................... 6 to 12 in. Quercus Palustris, Pin Oak, ............... 6 to 12 in. Quercus Palustris, Pin Oak, .................... Quercus Rubra, Red Oak, .......................... Quercus Rubra, Red Oak, ................. Quercus Velutina, Black Oak,................ Quercus Velutina, Black Oak,..................... Quercus Coccenia, Scarlet Oak, ............6 to 12 in. Quercus (ocenia, Scarlet Oak ...................... We probably have the largest stock of Oak in the world available today. We gatbered this seed ourselves and KNOW it is right.

Robinia pseudo-acacia, Black Locust, (trans.) .....12 to 18 in. Robinia pseudo-acacia, Black Locust, “ $\ldots 2$ to $3 \mathrm{ft}$. Rosa-blanda, seedlings, 2-yr.,

Rosa-Carolina, seedlings, 2-yr.,

Rosa-lucida, seedlings, 2-yr.,

Rosa-multiflora,

Rosa-multiflora,

“. …

“ $\quad \ldots .12$ to 18 in.

“. .....12 to 18 in.

، $\quad \cdots 66$ to 12 in.

“ .....12 to 18 in.

Rosa-Manetti, (strong trans.) .....................

Rosa-Rugosa, Japanese Rose, ................

Rosa-Setigera, Prairie Rose .......................

Rosa, White Dorothy, (strong trans.) ............. 2 to $4 \mathrm{ft}$.

Rosa-Dorothy Perkins, (trans.).............. 2 to $4 \mathrm{ft}$. We have 10,000 Extra fine Dorothy; they cannot be excelled. Just right for next Easter.

Rhus-Aromatica, ...................... 12 to 18 in.

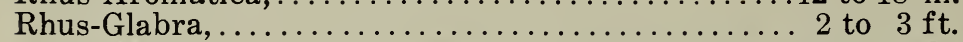

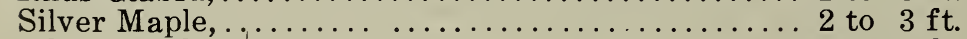
Silver Maple, ......................... 3 to $4 \mathrm{ft}$.

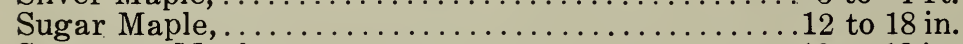

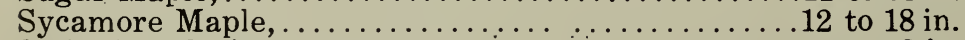

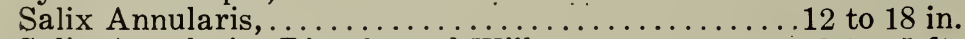
Salix Annularis, Ring-leaved Willow, ............ 3 to $5 \mathrm{ft}$. Salix Dolorosa, Wisconsin Weeping, ............ 3 to $4 \mathrm{ft}$.

Salix Pentandra, Laurel leaved, . ............ 2 to $3 \mathrm{ft}$.

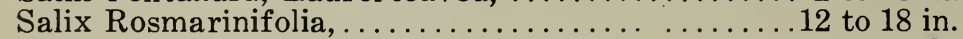
Salix Rosmarinifolia, Rosemary Willow........... 2 to $3 \mathrm{ft}$. Salix Russian Golden........................ 2 to $3 \mathrm{ft}$.

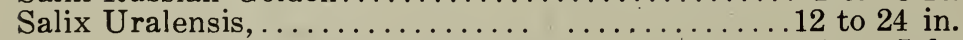

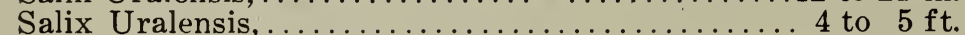
Salix Vitellina Aurea, Golden Willow, ........... 2 to $3 \mathrm{ft}$. Salix Babalonica, from Pekin, China,........... 3 to $4 \mathrm{ft}$.

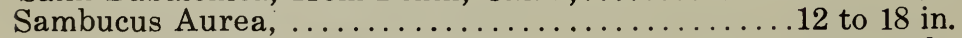
Sambucus Canadensis Elderberry, ............... Sambucus Nigra laciniata,...................... 18 to 24 in. Symphoricarpus Vulgaris, Indian Currant,...... 2 to $3 \mathrm{ft}$.

Per 1000

10000

1000

2000

2000

1500

2000

2500

3500

4000

35000

35000

5000

2000

3000

3000

3500

1500

2000

2000

1500

2000

1000

1500

1000

1500

1200

1500

500

1000

2500

2500

2000

1000

2000

2000

2000

2500

10000

10000

$50 \quad 00$

3000

800

1500

1500

1000

2000

2500

3000

3500

2000

$50 \quad 00$

2000

1000

2500

2000

$40 \quad 00$

3000

4000

6000

8000 


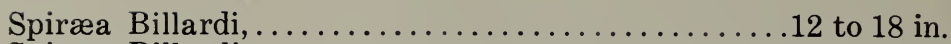

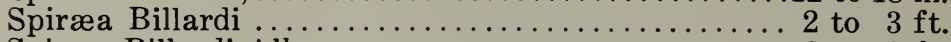

Per 1000

$\$ 2000$

8000

Spiræa Billardi Alba,................. 2 to $3 \mathrm{ft}$.

8000

Spiræa Billardi, White,................... 12 to 18 in.

2000

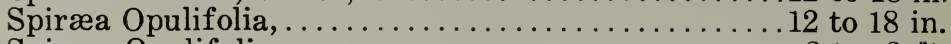

2000

8000

1500

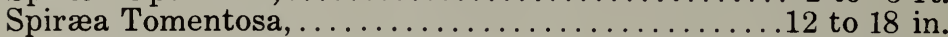

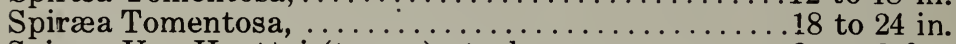

2500

8000

2500

Taxodium distichum, deciduous Cypress, ......... 6 to 12 in.

Tacoma-radicans, Trumpet Vine, ................

Ilix Glabra, Inkberry, .............. Strong collected, each

Ulmus Americana...................... 6 to 12 in.

2000

25

350

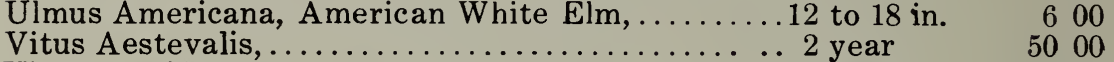

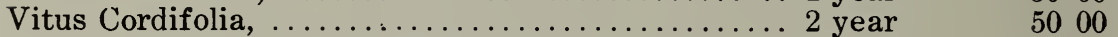

Vitus Labruska, Fox Grape $\ldots \ldots \ldots \ldots \ldots \ldots \ldots 2$ year $\quad 6000$

Vitus Rotundifolia, Muscadine Grape,.......... 1 year $\quad 3000$

Viburnum Plicatum, Japan Snowball,....... 3 to $4 \mathrm{ft}$. each 18

Wistaria-Magnifica, (strong trans.) ............ 3 to $4 \mathrm{ft} . \quad 10000$

\section{Cone Bearers or Evergreens.}

Pinus Ponderosa, Western Yellow Pine,........ 2 to 3 in.

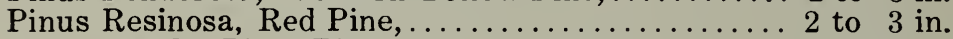

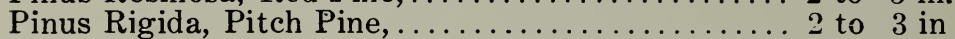

Pinus Sylvestris, Scotch Pine, (trans.) each. . . . 5 to $6 \mathrm{ft}$.

Pinus Taeda, Loblolly Pine, ................. 2 to 4 in.

Pinus Taeda, Loblolly Pine,$\ldots \ldots \ldots \ldots \ldots \ldots \ldots 4$ to 6 in.

Per 1000

$\$ 500$

1000

1000

50

600

1000

Pinus Thunbergi, Japanese Black Pine, ......... 2 to 4 in. $\quad 800$

\section{Hardy Perennials, Strong Field Grown}

Achillea, The Pearl, Double white, ............... Per 100

Achillea Millifoliun, Red, ................................ 500

Boltonia Asterordes, ............................. 500

Cereopsis Lancolata, ............................... 500

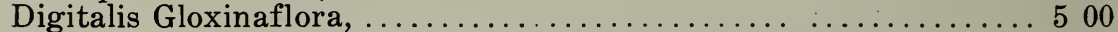

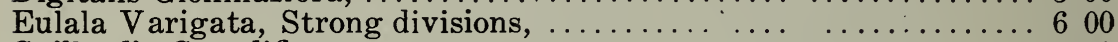

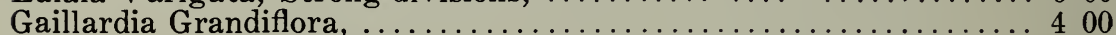

Iris German Assorted Named, .......................... 400

Lathyrus Latefolius, Perennial Sweet Pea, ................ 500

Monarda Dydima, Scarlet, ......................... 500

Pentstenun Digitalis, ............................... 800

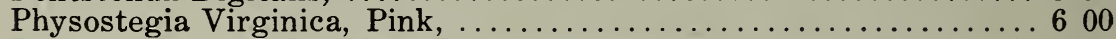

Ranunculus Acris Fl. Plena Buttercup, ................. 500

Rudbeckia, Golden Glow, ............................... 400

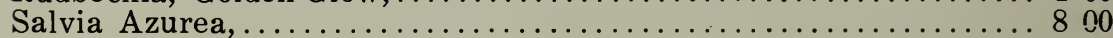

Solidago, (Golden Rod) Canadensis, .......................... 400

Spiræa Ulmaria Fl. Plena, .......................... 800

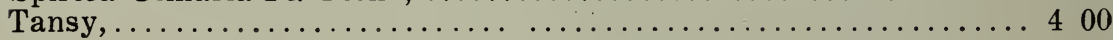

NARCISSUS BULBS. Home grown. Nice No. 2 round Bulbs, all flowering sizes.

Per 100

Barri Conspicus, Mrs. Langtry, Stella,.................\$6 00 Emperor, Empress, Grandee bicolor, Alba Plena Odorata, Sulphur

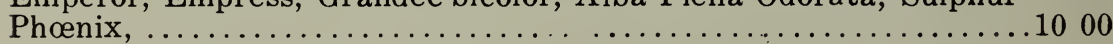

HARDWOOD CUTTINGS. Hand Made. No. 1 vigorous stock. We will have a surplus of Deutzia Cornus, Populus, Salix and some other sorts. If interested, get our prices. 


\section{FRUIT DEPARTMENT}

We have the following apples in strong three year buds: Fameuse, York, Northern Spy, Wolf River, Rome Beauty, Yellow Transparent, Wagner and Yellow Newton.

6 to $8 \mathrm{ft} .2$ in. and up per $100 \ldots \ldots \ldots \$ 2000$

5 to $7 \mathrm{ft} .11-16$ in. and up per $100 \ldots \ldots 1200$

4 to $6 \mathrm{ft} .5-8$ in. to $11-16$ in. per $100 \ldots .800$

4 to $5 \mathrm{ft} .1-2$ in. to $5-8$ in. per $100 \ldots \ldots 600$

We have the following apples in two-year buds and grafts, extra nice stock: Baldwin, Delicious, Fameuse, Grimes' Golden, King David, Rome Beauty, McIntosh Red, Northern Spy, Stayman, Spitzenberg, Stark, Winter Banana, Wealthy, Wolf River, Wagner, Yellow Transparent, York, Yellow Newton. Prices same as above.

DWARF PEAR, 2 year. Bartlett. 3 to $4 \mathrm{ft}$. 10c each.

CHERRY. The Compass. 3 to $4 \mathrm{ft}$. $15 \mathrm{c}$ each.

\section{Grape Vines, strong three-year, No. 1.}

Agawam-large, red . . . . . . . . . . . \$500

Concord - the old standby, black . . . . . . . . . . 400

Moore's Early-black, large . . . . . . . . . 600

Worden-black, a week earlier than Concord . . . . . . 500

CURRANTS. Red, White and Black varieties.

1 year No. 1, $\$ 2.00$ per 100, 1 year No. 2, $\$ 1.50$ per 100 .

\section{Asparagus Plants.}

Conover's, Barr's, Palmetto and Columbian White.

Strong 1-yr. plants, $\$ 300$ per 1000 . Strong 2-yr. plants, $\$ 500$ per 1000 .

\section{Strawberry Plants}

Brandywine, Big Joe, Excelsior, Glen Mary, Gandy, Haverland, Klondyke, Missionary, Chesapeake, Marshall, Nick Ohmer, Sample, Senator Dunlap, Rewastico, Wm. Belt and Michel's Early.

The above Strawberry plants at 50c per hundred, $\$ 4.00$ per thousand.

Superb and Progressive, Fall-bearing, $\$ 1.00$ per 100 , $\$ 8.00$ per 1000 .

DAFLLIAS. We have no great surplus this year, but have a good stock of a good many leading kinds. Will be pleased to price your list of wants. We have several Choice New Seedlings of great merit. If you are interested in Dahlias will be pleased to hear from you.

GLADIOLI. We have good stocks (true to name) of America, Augusta, Brenchelensis, Chicago White, Groff's Hybrids, Hollanda, Independence, Mrs. Francis King, Mrs. Frank Pendleton, Princeps, Peace, Panama, Niagara and others. Prices subject to correspondence.

Besides the stock mentioned in this list we are in a favorable position to supply dealers with a full line of Fruit and Ornamental stock, and will be pleased to receive your want list. We also have a good many items in small quantities not mentioned in our list. Prices subject to correspondence.

\section{SPECIAL ATTENTION}

We are decidely human - we have the same hopes and ambitions, the same joys and sorrow's as others, and cur full share of regrets and dissapointmehts. Our greatest regret at present, is that the conditions still prevailing abroad are causing our people to withhold the planting of stock, (especially ornamental) that there will SURELY be a great demand for for years to come. There are innumerable items in our stock which will find a ready sole and return you a substantial profit in handling.

We value your good opinion, esteem your orders, and assure you we are ever ready to make good a mistake and uphold our obligations. Our policy is broad and liberal, and we guarantee for every dollar to make an equal return in value.

Your Special Attention is called to the fact that we want Your Trade. We have taken extra care to grow stock that will please you and we know we have it. That's what we are here for - to supply you with stock grown right here athome, taken up when you want it, (no storage,) carefully packed to reach you in splendid growing condition. No delay. No war, ocean or other risks to run. We expect to do all in our power to Push American Grown Planting Stock to the Top. We want you to help us. Now is the time. 
